\title{
Flight Paths of Migrating Golden Eagles and the Risk Associated with Wind Energy Development in the Rocky Mountains
}

\section{Trajectoire de vol d'Aigles royaux en migration et risques associés au développement éolien dans les Rocheuses}

\author{
Naira N. Johnston $^{I}$, James E. Bradley ${ }^{1}$, Andrea C. Pomeroy ${ }^{1}$ and Ken A. Otter $^{I}$
}

\begin{abstract}
In recent years, the eastern foothills of the Rocky Mountains in northeastern British Columbia have received interest as a site of industrial wind energy development but, simultaneously, have been the subject of concern about wind development coinciding with a known migratory corridor of Golden Eagles (Aquila chrysaetos). We tracked and quantified eagle flights that crossed or followed ridgelines slated for one such wind development. We found that hourly passage rates during fall migration peaked at midday and increased by $17 \%$ with each $1 \mathrm{~km} / \mathrm{h}$ increase in wind speed and by $11 \%$ with each $1{ }^{\circ} \mathrm{C}$ increase in temperature. The propensity to cross the ridge tops where turbines would be situated differed between age classes, with juvenile eagles almost twice as likely to traverse the ridge-top area as adults or subadults. During fall migration, Golden Eagles were more likely to cross ridges at turbine heights (risk zone, $<150 \mathrm{~m}$ above ground) under headwinds or tailwinds, but this likelihood decreased with increasing temperature. Conversely, during spring migration, eagles were more likely to move within the ridge-top area under eastern crosswinds. Identifying Golden Eagle flight routes and altitudes with respect to major weather systems and local topography in the Rockies may help identify scenarios in which the potential for collisions is greatest at this and other installations.
\end{abstract}

RÉSUMÉ. Récemment, les contreforts des Rocheuses dans le nord-est de la Colombie-Britannique ont attiré l'attention comme site potentiel d'un développement éolien industriel, tout en faisant simultanément l'objet de préoccupations puisque ce projet coïnciderait avec un corridor de migration connu d'Aigles royaux (Aquila chrysaetos). Nous avons suivi et quantifié les vols d'aigles qui ont traversé ou longé les lignes de crêtes visées par un projet éolien de ce genre. Nous avons constaté que le taux de passage horaire durant la migration automnale atteignait un maximum à midi et augmentait de $17 \%$ pour chaque $\mathrm{km} / \mathrm{h}$ d'augmentation de la vitesse du vent, et de $11 \%$ pour chaque ${ }^{\circ} \mathrm{C}$ d'augmentation de la température. La propension à traverser les sommets des crêtes où seraient installées les éoliennes différait selon les classes d'âge, les jeunes aigles de l'année ayant deux fois plus de chance de le faire que les adultes ou les jeunes plus âgés. Durant la migration automnale, les aigles traversaient davantage les crêtes à hauteur d'éoliennes (zone de risque, $<150 \mathrm{~m}$ au-dessus du niveau du sol) sous un vent de face ou arrière, mais cette tendance diminuait avec l'augmentation de la température. En revanche, durant la migration printanière, les aigles étaient plus susceptibles de survoler la région des sommets sous un vent latéral de l'est. La détermination des trajectoires et des altitudes de vol des Aigles royaux, selon les systèmes météorologiques prédominants et la topographie locale des Rocheuses, peut contribuer à identifier les scénarios dans lesquels les risques de collision sont les plus élevés, que ce soit pour ce projet éolien ou d'autres.

Key Words: Aquila chrysaetos; collision risk; flight behavior; Golden Eagle; migration; Rocky Mountains; weather patterns; wind energy

\section{INTRODUCTION}

Concerns over collisions exist where areas of high raptor concentrations overlap with wind energy developments (Duinker and Greig 2006, Drewitt and Langston 2008, Katzner et al. 2008, 2012). Soaring raptors are often at greater risk of collision than other birds because of their reliance on wind currents channeled by topography for lift (Barrios and Rodríguez 2004, Drewitt and Langston 2008, Katzner et al. 2012, Lanzone et al. 2012). For k-selected species, such as the Golden Eagle (A. chrysaetos L. 1758), even small numbers of fatal collisions could deleteriously affect population levels (Carrete et al. 2009). With the increase of wind energy

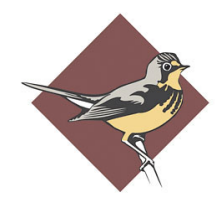

BIRD STUDIESCANADA 
developments built in new areas used by soaring raptors, techniques are needed to document fine-scale species-specific movement patterns within developments to better understand and predict collision risk (Ferrer et al. 2012, Lanzone et al. 2012).

Complex mountain terrain is often favored by large-bodied soaring species during migration because of the enhanced opportunities for lift, i.e., slope winds, deflected winds, and thermals, compared with areas of flatter terrain (Kerlinger and Moore 1989, Hedenstrom 1993, Spaar and Bruderer 1996, Yates et al. 2001, Mandel et al. 2008, Katzner et al. 2012, Lanzone et al. 2012). By using vertically rising air, soaring migrants can maintain energy expenditures that are little above resting state (Weimerskirch et al. 2000, Mandel et al. 2008) and so minimize the costs of migration. Golden Eagle migration in western North America is concentrated along the eastern Rocky Mountains, where the prevailing winds originate perpendicularly to the direction of travel (Brodeur et al. 1996, Alerstam 2001, Bildstein 2006, McIntyre et al. 2008). The orographic lift that results from deflected strong SW winds in the fall results in a migration highway, a favored route used for fast and steady travel by raptors (Bittner 2010).

Postconstruction research at wind energy developments, however, suggests that fatality events are not always related to relative species abundance within a region (Lekuona and Ursua 2007, de Lucas et al. 2008, Ferrer et al. 2012). Rather, fatality events vary depending on species-specific flight behavior, which is determined by local weather, topography, or mode of flight (Barrios and Rodríguez 2004, Hoover and Morrison 2005, Smallwood 2007). For example, some evidence suggests that collision risk for raptors at wind energy developments in southern Spain is greater for breeding and overwintering populations compared with those migrating to or from African wintering grounds (Barrios and Rodríguez 2007, although see de Lucas et al. 2012). Similarly, high numbers of raptor collisions have been reported in California, United States, where wind energy developments overlap with known foraging and overwintering grounds of raptors, including Golden Eagles (Orloff and Flannery 1992, Hunt 1995, Thelander and Rugge 2001, Smallwood and Thelander 2004, 2008, Smallwood et al. 2009). Although this effect on raptor populations in California had been blamed on the historic use of numerous small turbines, compared with new or repowered developments, that hypothesis has not been formally tested (Smallwood and Karas 2009, Smallwood and Neher 2009). Many collision events involving resident/ overwintering soaring raptors appear to be correlated with the amount of time individuals spend flying within the rotor-swept areas of the turbines, rather than turbine size; these high-risk flights increase under low-wind conditions when birds may be both flying slowly and circle soaring near turbines (Barrios and Rodríguez 2007).
We estimated 3-D flight paths of Golden Eagles during two fall migration seasons and one spring migration season prior to construction of the Dokie 1 Wind Energy Project, hereafter called Dokie 1. We then tested whether particular weather/ topography interactions increased the frequency of eagle flight onto the proposed project footprint. To demonstrate this, we (1) identified weather conditions associated with the variation in both hourly passage rates and frequency of flights over the ridge-top area, a 100-m buffer along the midline of the ridge following the proposed turbine string; (2) assessed the effect of passage route through the site, time of passage, and eagle age on the probability that an eagle flew over the ridge-top area; and (3) identified whether any of these variables affected the probability of movement within a ridge-top predefined risk zone, below rotor-swept height $(\mathrm{RSH} ; \leq 150 \mathrm{~m}$ above ground level [agl]). Although we evaluated potential collision risk at a site-specific scale, the consistency of terrain and weather patterns throughout the eastern Rocky Mountains makes this research relevant for similar predictions of collision risk across a large part of the Golden Eagle migration corridor.

\section{METHODS}

\section{Study area}

Dokie $1\left(55^{\circ} 46^{\prime} 28^{\prime \prime} \mathrm{N}, 122^{\circ} 16^{\prime} 48^{\prime \prime} \mathrm{W}\right)$ is located in the Hart Range of the eastern Rocky Mountains in northeastern British Columbia, a $13,584-\mathrm{km}^{2}$ region specifically identified as experiencing significant wind energy development (Larson 2010; Fig. 1). The Hart Range is also part of a known Golden Eagle migration corridor that follows the Rocky Mountains from Alaska/Yukon to wintering grounds in the mid- and southwestern United States (Omland and Hoffman 1996, Yates et al. 2001, Sherrington 2003, McIntyre et al. 2008, Bittner 2010). Dokie 1 is the first operational facility within the Hart Range, and the site topography and weather are representative of those found throughout the Hart Range and the eastern Rocky Mountains (Yates et al. 2001, Sherrington 2003). In this area, ridges are consistently aligned NW-SE because of extensive thrust faulting, and wind conditions are characterized by medium-strong SW winds, mostly in the fall, or light NE winds, mostly in the spring, accompanied by low clouds (Yates et al. 2001, Sherrington 2003).

Dokie 1 consists of two ridges: The 4.5-km "Johnson Col" (JC; mean elevation $1200 \mathrm{~m}$ ), hereafter called the study site, is oriented approximately north-south, parallel to migration pathways, and abuts a deep, wide valley to the west. The study site has 15 of the 48 proposed 3-MW Vestas turbines, with the remainder on the $6 \mathrm{~km}$ long "Johnson Ridge" (mean elevation $1375 \mathrm{~m}$ ) to the east and separated from the study site by a shallower valley (Fig. 2). Previous work had shown the study site to have higher eagle passage during fall migration (A. C. Pomeroy, N. N. Johnston, M. Willie, M. Preston, C. Bailey, M. d'Entremont, and K. A. Otter, unpublished manuscript). 
Fig. 1. Location of the Dokie 1 Wind Energy Project in the eastern foothills of the Rocky Mountains, Peace River

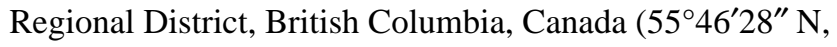
$\left.122^{\circ} 16^{\prime} 48^{\prime \prime} \mathrm{W}\right)$. This project is located within the Hart Range, which is experiencing significant prospecting and construction of a number of wind energy installations.

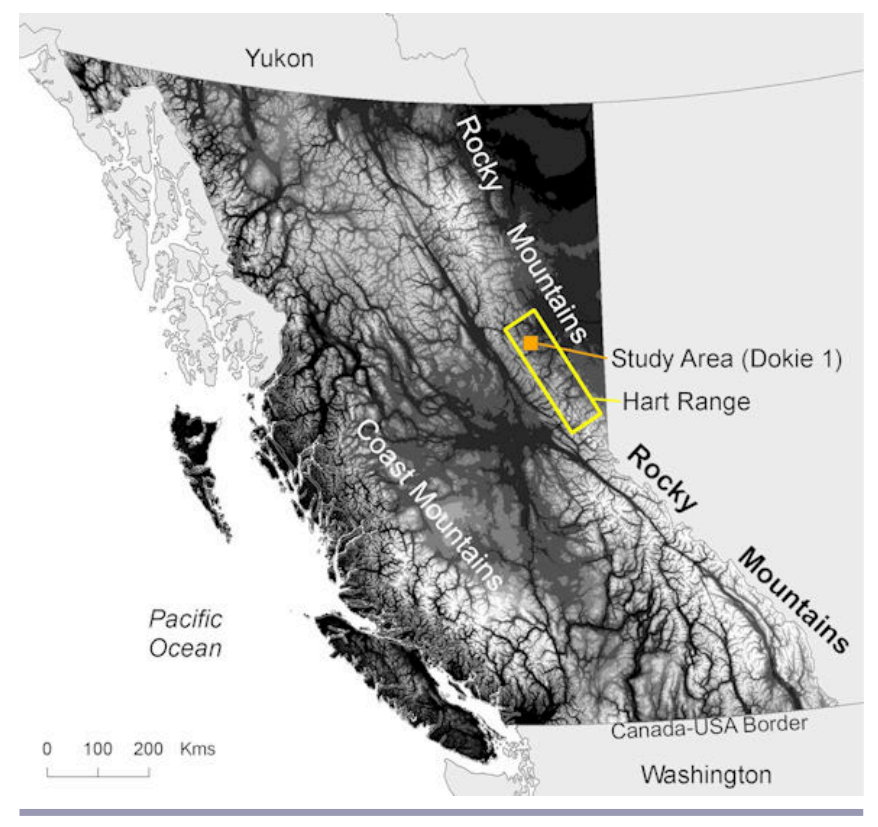

During both the fall 2009 and spring 2010 migration seasons, only three idle turbines, spaced $1.5 \mathrm{~km}$ apart, were standing on the study site (Fig. 2). The 2008 fall season had only one idle turbine standing at the north end of the study site. The turbines were $80 \mathrm{~m}$ in height to the hub, with $47-\mathrm{m}$ blades, resulting in a maximum RSH of $127 \mathrm{~m}$ and span of $94 \mathrm{~m}$. We considered the midconstruction phase as essentially undeveloped because there was no ongoing turbine construction, and research indicates that birds do not exhibit avoidance behavior in response to idle standing structures (de Lucas et al. 2007). The ridge of the study site extends $1 \mathrm{~km}$ beyond the proposed northern-most turbine, JC15, and we treated this area as part of the study site even though it was not going to be part of the wind farm. This allowed us to consider movements over an entire ridge feature and provided the potential for using this area as a control for postconstruction monitoring (Fig. 2).

\section{Observations}

We observed migrating Golden Eagles for 217 hours in fall 2008 (36 hours) and 2009 (181 hours) and 63 hours in spring 2010, accounting for time lost because of inclement weather. Observations were conducted between 2 October and 9 October 2008 and 13 September and 24 October 2009 in the fall, and between 17 March and 28 March 2010 in the spring. Two observers worked together each day and performed consistent duties throughout all seasons, one as the observer and the other as the recorder. Observations were rotated between three discreet observation points to achieve a balanced sampling regime between time of day and area covered. Observation periods extended for $3 \mathrm{~h}$, and two were conducted concurrently between 0900 and 1530 Pacific daylight time. Each observation point (Fig. 2) was selected to provide a proximate view of a different 1.5 to $2 \mathrm{~km}$ long section of the study ridge in addition to the surrounding valleys. Two were located within the study site itself, JC South and JC North, with JC South only in 2008, and one on the nearby Johnson Ridge North, which afforded the best view of the north end of the study ridge (Fig. 2). In the spring, we substituted a point $700 \mathrm{~m}$ farther north along the ridge for the observation point JC North to capitalize on an improved view of oncoming birds from the south.

Fig. 2. The Dokie 1 Wind Energy Project (northern section) in the eastern foothills of the Rocky Mountains of northeast British Columbia, Canada. Both the study area and area of ridge-top movements (includes within the risk zone $\leq 150 \mathrm{~m}$ and/or above) represents a $2-\mathrm{km}$ and $100-\mathrm{m}$ buffer around the turbine string, respectively. Arrows represent east and west migration routes used by Golden Eagles (Aquila chrysaetos) through the site for both fall (southward) and spring (northward) seasons.

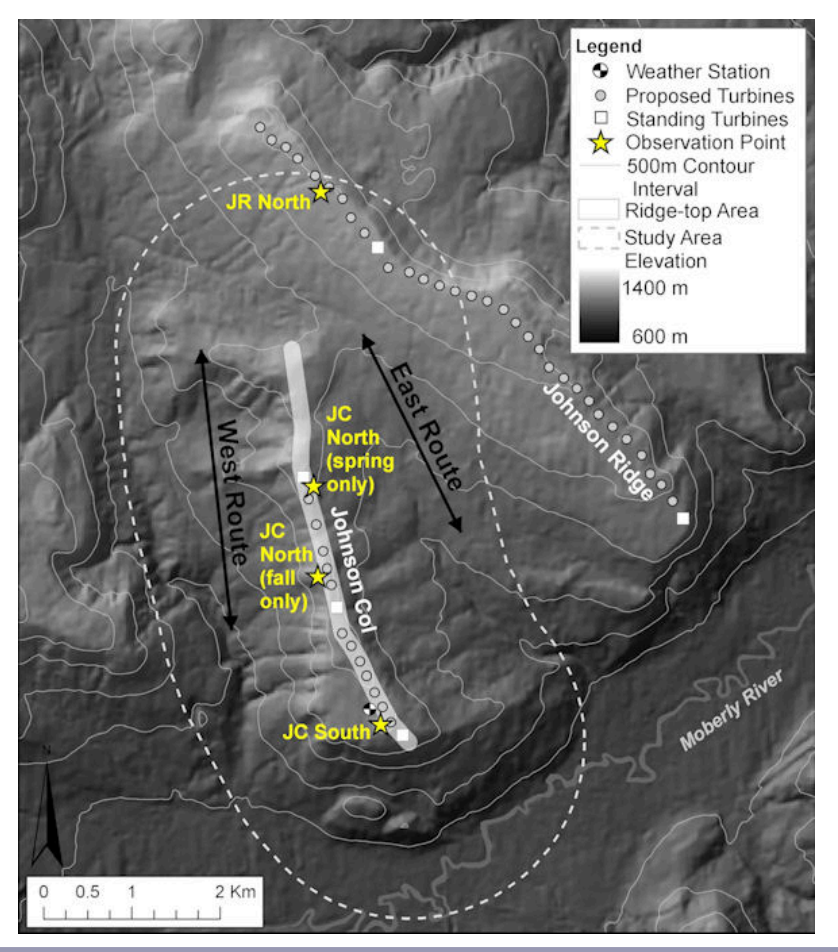


We aged every Golden Eagle based on plumage characteristics (Liguori 2004). Age categories included experienced migrants, inexperienced migrants, and unknown. Experienced birds included both adults and subadults, 2-5 years old; whereas inexperienced birds included individuals with juvenile plumage characteristics. We used visual observations to estimate an eagle's location by ascertaining the position of the bird relative to the observer at regularly spaced points along the ridge. We collected location point data by combining a compass bearing to the bird for horizontal position, a clinometer angle for vertical position, and an estimation of horizontal distance to the bird to allow for a subsequent calculation of bird height. To be confident that we estimated distances consistently and as accurately as possible, we used the same observer, J. E. Bradley, for all data collection considered for analysis of flight height (2009, 2010; Band et al. 2007). We estimated distances with the use of known landmarks, idle turbines, power poles, and cleared forest areas, as well as satellite imagery maps with superimposed distance rings. During periods between data collection, the observer/ recorder tested distance estimation of the observer against stationary objects in the landscape, confirming estimations against maps. Range estimation error increases with distance from the observer but was estimated at 10\%-15\% overall error at any given distance, thus $<150-\mathrm{m}$ error at $1 \mathrm{~km}$. Given the shallow clinometer angles associated with low-flying eagles, a $15 \%$ distance estimation error at $1 \mathrm{~km}$ for a bird assessed at $150 \mathrm{~m}$ agl would translate to approximately a $23-\mathrm{m}$ error in height estimation. Thus, we considered flying $150 \mathrm{~m}$ agl as risky flight behavior to account for this height estimation error, rather than the actual upper turbine blade reach $(127 \mathrm{~m})$. In addition, we only collected location data for eagles that moved in the expected migration direction, so as to exclude nonmigratory movements.

We collected on average 6 location points per migrating bird. However, this decreased slightly with increasing numbers of eagles being tracked at a time. Upon first sight of an eagle at $2 \mathrm{~km}$, or closer if first detected within that distance, we estimated a 3-D point. Points were then repeatedly collected with any perceived change in flight behavior or direction until the eagle left the site $(2 \mathrm{~km})$. We increased the number of points sampled for birds that came within $1 \mathrm{~km}$ of the study ridge (mean 8 points per bird) and for birds that moved over the ridge-top area, or proposed turbine string (mean 10 points per bird). Additionally, for any eagle that flew near the ridgetop area, we noted whether it was above or below RSH $(\leq 150$ $\mathrm{m})$ for comparison with height classifications obtained using a geographic information system (GIS; ArcMap, version 9.5, Environmental Systems Research Institute, Redlands, California, USA). The average distance for obtaining eagle heights over the ridge-top area was $640 \mathrm{~m}$, with only a few distances estimated at $1 \mathrm{~km}(n=2)$. Comparison of flight heights obtained using GIS in this manner also agreed with field estimates of above or below RSH in all but a few exceptions; these discrepancies occurred when eagle heights were on the boundary of inclusion in RSH, i.e., 140-150 m agl, in which case we used the GIS height data. This further confirmed the reliability of the distance/height estimation of the two-observer method described previously.

We collected weather data at $2 \mathrm{~m}$ agl from an Onset HOBO (Onset, Bourne, Massachusetts, USA) weather station located at the south end of the study ridge in an exposed, treeless area (Fig. 2). The data logger averaged and recorded temperature, wind direction, wind speed, barometric pressure, and relative humidity at 5-min intervals. We also estimated cloud cover hourly. We used the power law approximation method, or power law, to determine the ground-based, 2-m wind speed that corresponded with that required for turbine cut-in, i.e., the wind speed required for the turbine blades to begin rotation $(14 \mathrm{~km} / \mathrm{h}$, or $4 \mathrm{~m} / \mathrm{s})$, as measured at nacelle height ( $80 \mathrm{~m} \mathrm{agl}$; Counihan 1975, Hanafusa et al. 1986, Segal and Pielke 1988, Zoumakis 1993). Using an alpha value of 0.25 for rough, treecovered terrain, we determined that a wind speed of $8.5 \mathrm{~km} /$ $\mathrm{h}$ at ground level corresponded with a $14 \mathrm{~km} / \mathrm{h}$ turbine cut-in speed at nacelle height. We then compared nacelle data to ground-based weather data collected in spring 2011 to test this technique and found a strong correlation between data collected at nacelle height with ground data adjusted using the power law $\left(R^{2}=0.91\right)$. All analyses on eagle flights within the risk zone in relation to wind speed used ground-level data adjusted with the power law.

Last, we considered categories a more practical approach to dealing with multicollinearity between wind speed and direction (Batschelet 1981). We created wind direction categories based on the general north-south axis of migration used through the site and were consistent between seasons: Winds originating from $136^{\circ}$ to $225^{\circ}$ were classified as headwinds in the fall or tailwinds in the spring; those from $226^{\circ}$ to $315^{\circ}$, as westerly crosswinds; those from $316^{\circ}$ to $45^{\circ}$, as fall tailwinds or spring headwinds; and those from $46^{\circ}$ to $135^{\circ}$, as easterly crosswinds (Fig. 3a, b). The prevailing SW wind direction in the fall included both headwinds and western crosswinds (Fig. 3a, b). We used Oriana (version 2.0, Kovach Computing Services, Anglesey, Wales, UK) to average and plot circular wind direction data.

\section{Data preparation}

Location data for each bird consisted of a series of Universal Transverse Mercator (UTM) coordinates in addition to an altitude for each point. Using GIS, we projected bird location points into UTM positions that included an associated altitude estimation and used ET Geowizard (ET Spatial Techniques, Pretoria, South Africa, http://www.ian-ko.com) to connect location points to recreate 3-D Golden Eagle flight tracks. This provided a spatial perspective on eagle passage and allowed for identification of individual eagles that passed within a 
Fig. 3. Stepped circular histogram of ground-based hourly wind speed by direction for (a) fall migration seasons (2-9 October 2008 and 13 September and 24 October 2009); and (b) spring (17-28 March 2010), between 0900 and 1530 hours Pacific Standard Time. Turbine cut-in speed (wind speed at which turbine blades start spinning) at ground level is $8.5 \mathrm{~km} / \mathrm{hr}(14 \mathrm{~km} / \mathrm{hr}$ at nacelle height). Zero values: fall $1.48 \%$; spring $2.11 \%$. Note different y-axes between seasons.

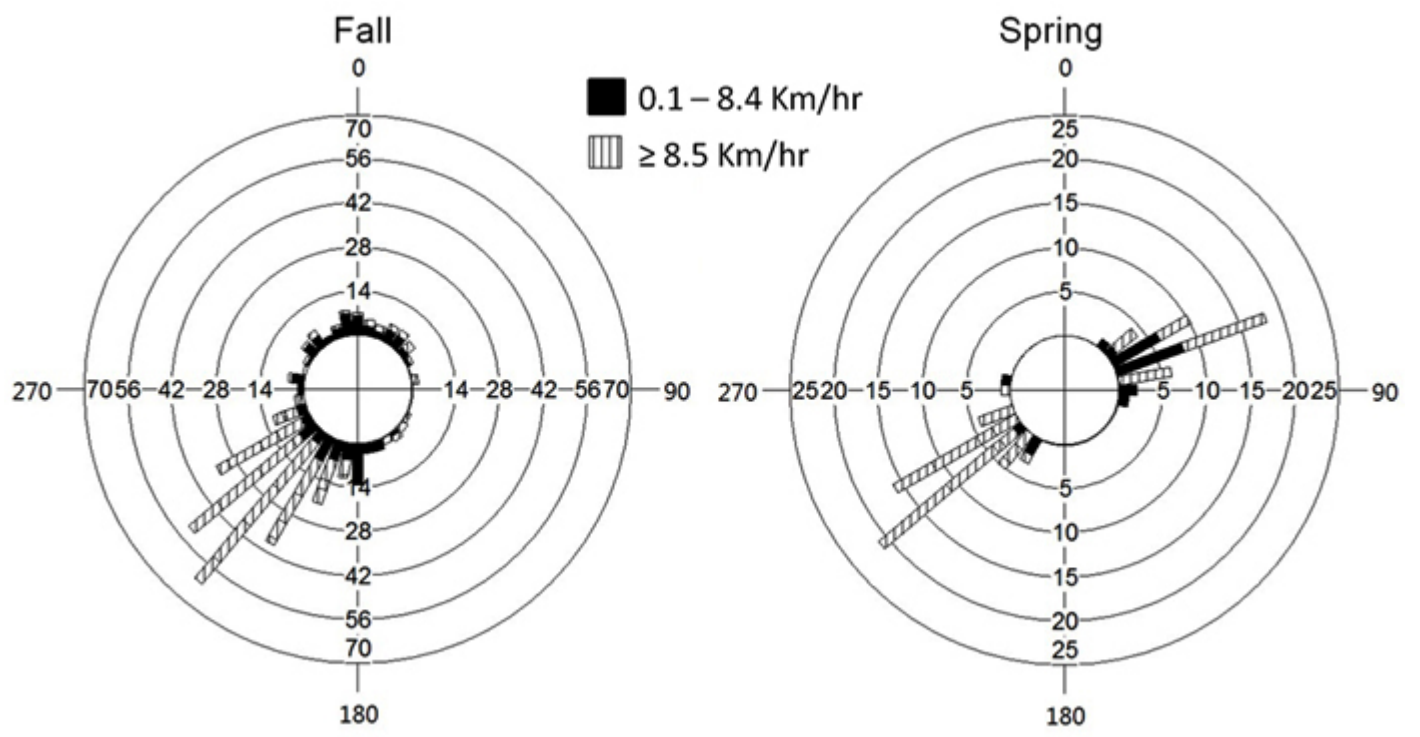

buffer region placed on a 100-m radius around the proposed turbine string and extending the full length of the ridge, i.e., ridge-top movement (Fig. 2).

We included all movements into this ridge-top area, regardless of whether the birds crossed the ridgeline or followed parallel to its axis (Barrios and Rodríguez 2004, de Lucas et al. 2004, Lekuona and Ursua 2007, Smallwood et al. 2009). We included one point of entry for each eagle detected and used the first point of entry for eagles that crossed into the zone multiple times. The 100-m zone along each side of the apex of the ridge represents a 50-m lateral buffer beyond the length of the turbine blades to account for error attributable to distance estimations, and it includes spaces between turbines (approximately $250 \mathrm{~m}$ ), thus providing a conservative estimate of potentially risky preconstruction flight behavior. Birds entering this buffer region at heights $\leq 150 \mathrm{~m}$ were considered to be in the "risk zone." This risk zone included the RSH of turbines (33-127 $\mathrm{m} \mathrm{agl}$ ), plus the 0-27 $\mathrm{m}$ below RSH and the 23-m span above RSH; this broadened zone was intended to counteract potential errors in height estimation and thus provide a conservative estimate of high-risk flights.

We classified eagle paths as either "eastern" or "western" relative to the ridge. Eagles for which approach route information was lacking were assigned a route based on whether the majority of the track was within the given route. Eagles that were first detected flying above the ridge top, or those that had too short of a track to determine route, were not categorized (Fig. 2).

\section{Statistical methods}

We treated spring and fall data as discreet data sets and completed all analyses separately for each season. We used generalized linear regression models (GLMs) for analysis of both passage rates and frequency of movements over the ridgetop area. The predictor variables for both models included mean hourly barometric pressure (mbar); wind speed $(\mathrm{km} / \mathrm{h})$; temperature $\left({ }^{\circ} \mathrm{C}\right)$; cloud cover $(\%)$; wind direction, i.e., headwind, east or west crosswind, or tailwind; year, fall only; date, Julian; and hour. We included a second-order polynomial term for date in all models to describe the bell-shaped curve of passage with date. In our hourly passage rate model, we included an interaction term between wind speed and hour to determine if hourly passage differed on days with strong winds compared with days with weak winds, and we included second-order polynomial terms for continuous weather variables. For our analysis of hourly movements over the ridge-top areas, we included interactions between wind speed and cloud cover to identify potential patterns between days with low wind speeds and low solar radiation. We also included background passage rate as a predictor of ridge-top movements to assess the effect of site abundance on frequency of movements over the ridge-top area. In cases when ridgetop movements were highly correlated with background 
passage rates, we removed this predictor from the model because it obscured the weather conditions of interest.

Furthermore, where weather variables were potentially correlated, e.g., temperature and relative humidity, and wind speed and wind direction, we inspected predictor variables for correlation prior to model selection. If we observed a correlation, we retained the most significant variable. However, we tested both variables in final models to ensure that we selected the best representation of the effect. Data collected in fall 2008 were included in analyses of passage rates, but not in analyses of bird height into the risk zone because they were collected by multiple observers.

For all GLMs, we first used a Poisson distribution using forward selection based on the lowest Akaike information criterion (AIC) value (Crawley 2007). Final models within a $\triangle \mathrm{AIC}$ of 2 or less were considered, and the most parsimonious model was selected as our final model (Crawley 2007). This method produced at most one competing model within $\triangle$ AIC of 2 or less of the lowest value model and always involved the removal of an extra weather parameter, e.g., cloud cover. We used a dispersion test to evaluate the null hypothesis of equidispersion in a Poisson model (Crawley 2007). If we detected overdispersion, we used new models based on a negative binomial distribution (Venables and Ripley 2002, Zuur et al. 2009). We compared the most parsimonious negative binomial models to Poisson models for best fit using the Vuong test (Vuong 1989, Zuur et al. 2009). A negative binomial distribution handles overdispersion better than a Poisson distribution because it has an additional error term to handle extra variance with regard to the mean (Crawley 2007). We tested final models for fit against a null model using a likelihood ratio (LR) test (Zuur et al. 2009).

We used logistic regression models to analyze the probability of moving over the ridge-top area versus not moving into the ridge-top area, in addition to the probability of entry within the risk zone, i.e., below RSH $(\leq 150 \mathrm{~m})$, or not, i.e., above RSH (> $150 \mathrm{~m}$ ). Predictor variables considered in these analyses included eagle age, experienced or inexperienced; passage route taken, east or west of the study ridge; and/or weather conditions averaged over five minutes to provide more specific conditions. Similar to the first part of our analysis, we selected final models based on $\Delta$ AIC of $\leq 2$ of the lowest value model and selected the most parsimonious logistic regression model as our final model. We tested final models for fit against a null model using an LR test (Zuur et al. 2009) and used 10-fold cross-validation to obtain an estimate of predictive accuracy (Maindonald and Braun 2010). We back-transformed model estimates, in log units, for ease of interpretation; see table captions for details. We used the statistical software R, v. 2.8.1, for all analyses (R Development Core Team, http://www.r-project.org).

\section{RESULTS}

\section{Weather patterns}

During the fall, the vast majority of observation periods coincided with winds from the SW: $2008,85 \%$ of the time; and $2009,90 \%$ of the time. The NE tailwinds were less common: $2009,10 \%$ of the time; and 2008, $5 \%$ of the time (Fig. 3a). The NE winds were typically associated with light wind speeds and/or poor weather and visibility conditions, and eagle migration was less likely under such conditions.

Wind direction was more variable during the peak of spring migration in 2010, with a greater proportion of NE versus SW winds compared with the fall migration seasons (Fig. 3b). Aside from poor visibility under NE winds, the important difference for eagle migration is the difference in wind speed between these two prevailing wind directions. Ground weather data collected on-site in all seasons showed that winds from the NE were light and often did not reach wind speeds required for the movement of the turbine blades $(14 \mathrm{~km} / \mathrm{h}$ at nacelle height, or $8.5 \mathrm{~km} / \mathrm{h}$ at ground level; Fig. 3a, b).

\section{General migration patterns}

We observed a total of 92 Golden Eagles during focused sampling from 1 October to 10 October 2008, and 382 from 17 September to 24 October 2009 (Fig. 4a). Average Golden Eagle passage rates in the fall were 2.5 per hour in 2008 and 2.2 per hour in 2009. Maximum passage was 14 per hour in 2008 and 22 per hour in 2009. The days of highest Golden Eagle passage in the fall were 3 October $2008(n=49)$ and 5 October and 22 October 2009 ( $n=61$ and 46, respectively). All fall 2008 passage was documented under SW wind conditions, and only $4 \%(n=15)$ of the observed eagles in 2009 traveled in weak NE tailwinds. For both fall seasons combined, the majority $(82 \% ; n=388)$ of eagles migrated along the western route, compared with $14 \%(n=65)$ along the eastern route. We were not able to ascertain the route taken for approximately $4 \%(n=21)$ of the eagles observed. Fall migration was composed of mixed age classes throughout the migratory period. Approximately $47 \%(n=223)$ were identified as experienced migrants, i.e., adults or subadults; $23 \%(n=108)$ were identified as juvenile, or inexperienced, birds; and 30\% ( $n=143)$ were not identified to age (Fig. 4a).

Our most parsimonious model for fall Golden Eagle hourly passage identified an expected bell-curved, second-order pattern in relation to date. Hourly passage was 5 to 20 times greater in the hours around midday compared with early morning or late afternoon, increased by $17 \%$ with every kilometer per hour increase in wind speed, and increased by $11 \%$ with every degree Celsius increase in temperature (Table 1). In addition, hourly wind speed interacted with observation hour; hourly passage decreased by $16 \%$ with every kilometer per hour increase in wind speed in the hours around midday compared with the early morning or late afternoon (LR test $\chi^{2}$ 
Fig. 4. Golden Eagle (Aquila chrysaetos) flight tracks through the Dokie 1 Wind Energy Project site during fall 2009 migration separated by migratory experience: a) experienced migrants (individuals with adult and subadult plumage - yellow track lines); and b) inexperienced migrants (juvenile plumage - white track lines). Track lines in black represent birds of unknown age. Spring 2010 migration includes only experienced and unknown migrants c), because no birds with juvenile plumage were detected during these migrations.

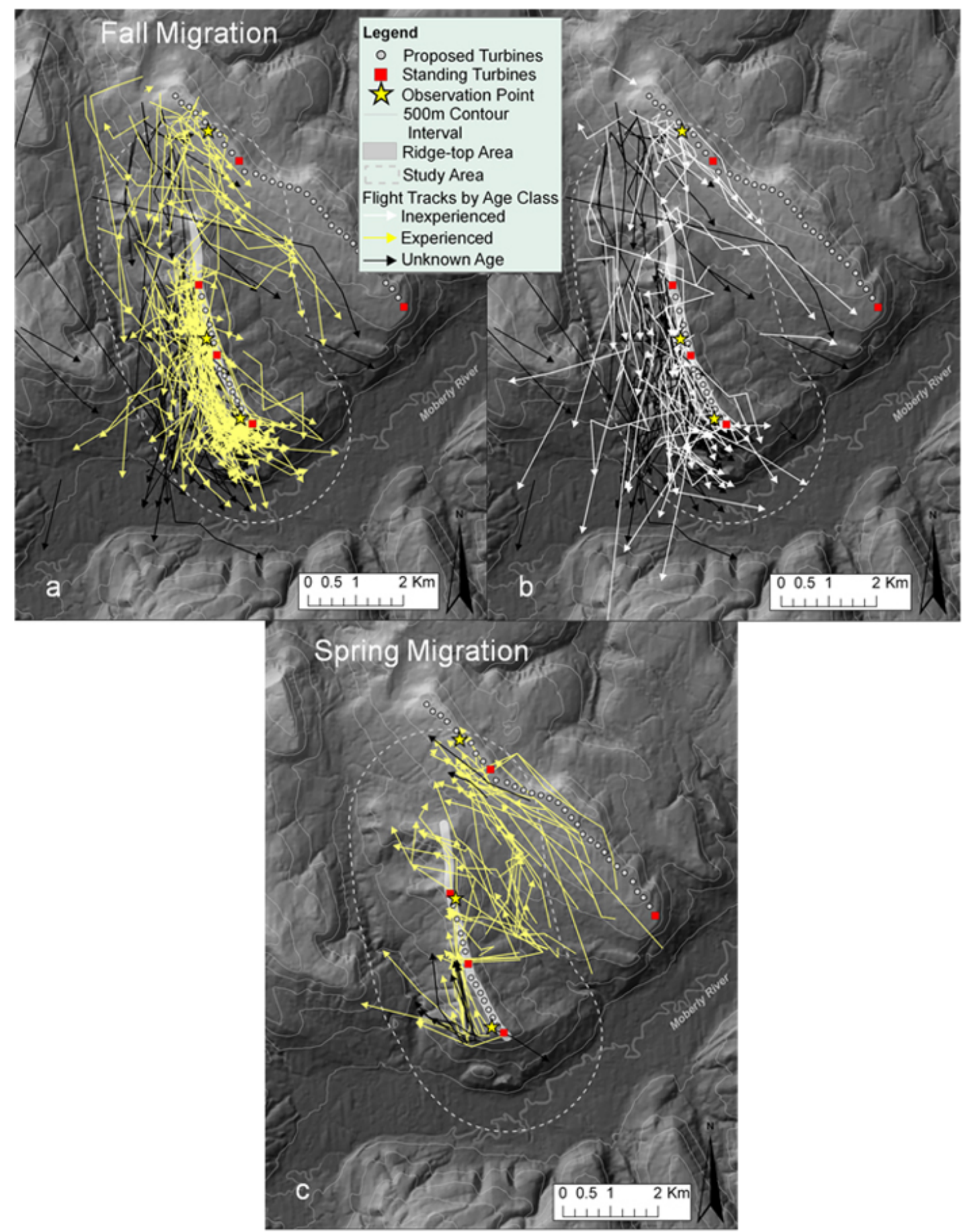


Table 1. Summary of multivariate negative binomial regression examining the association of temporal and environmental variables on the passage rates of Golden Eagles (Aquila chrysaetos) in the fall at the Dokie 1 Wind Energy Project between 2 9 October 2008, and 13 September - 24 October 2009.

\begin{tabular}{|c|c|c|c|c|}
\hline Term & Estimate & SE & $z$ & $p$ \\
\hline Intercept $^{\dagger}$ & -5.182 & 0.941 & -5.509 & $\leq 0.001$ \\
\hline Date & 0.315 & 0.050 & 6.339 & $\leq 0.001$ \\
\hline Date-squared & -0.006 & 0.001 & -5.655 & $\leq 0.001$ \\
\hline Wind speed ${ }^{\S}$ & 0.159 & 0.041 & 3.887 & $\leq 0.001$ \\
\hline Hour 1 & 1.224 & 0.925 & 1.324 & 0.185 \\
\hline Hour 2 & 1.794 & 0.897 & 2.000 & 0.455 \\
\hline Hour 3 & 3.328 & 0.869 & 3.826 & $\leq 0.001$ \\
\hline Hour 4 & 2.278 & 0.887 & 2.567 & 0.010 \\
\hline Hour 5 & 0.799 & 0.928 & 0.861 & 0.389 \\
\hline Hour 6 & -1.235 & 0.928 & 0.861 & 0.320 \\
\hline Cloud cover & -0.007 & 0.003 & -2.078 & 0.037 \\
\hline Temperature $^{\text {II }}$ & 0.102 & 0.026 & 3.858 & $\leq 0.001$ \\
\hline Wind speed: Hour 1 & -0.072 & 0.051 & -1.421 & 0.155 \\
\hline Wind speed: Hour 2 & -0.086 & 0.050 & -1.718 & 0.086 \\
\hline Wind speed: Hour 3 & -0.173 & 0.050 & -3.445 & $\leq 0.001$ \\
\hline Wind speed: Hour 4 & -0.099 & 0.050 & -1.975 & 0.048 \\
\hline Wind speed: Hour 5 & -0.027 & 0.051 & -0.527 & 0.598 \\
\hline Wind speed: Hour 6 & -0.002 & 0.064 & -0.028 & 0.978 \\
\hline
\end{tabular}

${ }^{\dagger}$ Response is number of Golden Eagles per hour. For example, to estimate the number of eagles on October 1 (day 16) at a wind speed of $15 \mathrm{~km} / \mathrm{hr}$, during hour 3 , with $5 \%$ cloud cover and at a temperature of $5^{\circ} \mathrm{C}, \log (\mathrm{y})=-5.182+(0.315 \times 20)-$ $\left(-0.006^{2} \times 20\right)+(0.159 \times 15)+3.328+(0.102 \times 5)+(-0.007 \times 5)+(-0.173 \times 15) ; \log (\mathrm{y})=3.447$. Therefore, $\mathrm{y}=\exp ^{(3.447)}$ $=31.41$ eagles $/ \mathrm{hr}$.

${ }^{\ddagger}$ Day 1 is 17 September

$\S \mathrm{km} / \mathrm{hr}$

I Percent

"I Degree Celsius

$=102.18, P \leq 0.001$; Table 1). This means that under lowwind conditions, passage in the morning and late afternoon is very low, but there is a sudden peak at midday. In contrast, under high-wind conditions there is both relatively greater movement in the morning/afternoon periods and more even movement throughout the day, although peak movement still centers on midday (Fig. 5).

Spring migration was more truncated than fall, with the majority of passage occurring between 17 March and 28 March in 2010, and consisted of fewer migrating individuals $(n=104$; Fig. 4b). The spring eagle passage rate was 1.4 per hour, with a maximum hourly passage of 16 per hour. Peak passage in the spring was observed on 24 March $2010(n=27)$. In contrast to the fall, when the majority of eagles traveled under SW winds, $43 \%(n=45)$ of observed eagles traveled in NE headwinds. Also contrary to the fall, the majority of eagles $(72 \%, n=73)$ used the eastern route compared with the western route $(28 \%, n=29)$. Around $87 \%(n=89)$ of eagles identified to age in the spring were adult birds, with only $2 \%(n=2)$
Fig. 5. Average number of Golden Eagles (Aquila chrysaetos) per hour observed during fall 2009 migration (13 September - 24 October) separated by wind speed (high $\geq 8.5 \mathrm{~km} / \mathrm{hr}$; low $<8.5 \mathrm{~km} / \mathrm{hr}$ ). X-axis represents the start of the observation hour.

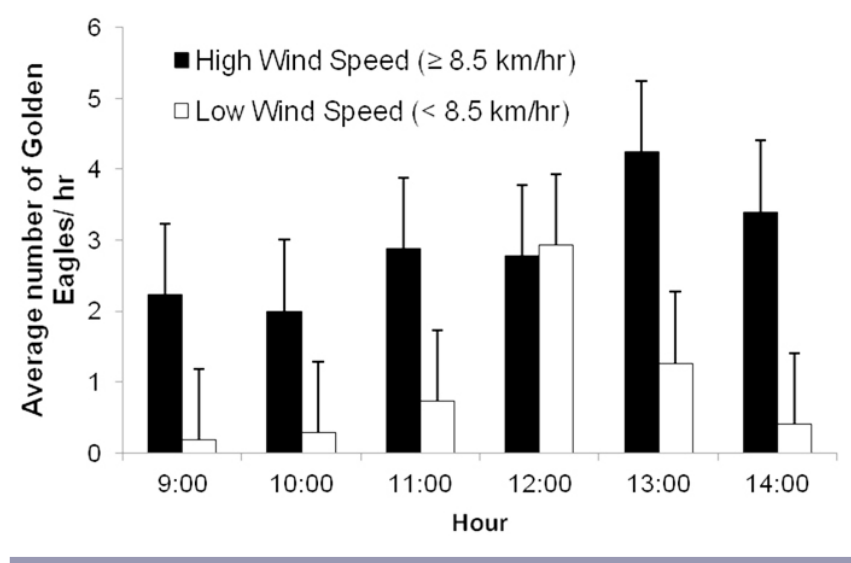


identified as subadult. Approximately $13 \%(n=13)$ were not identified to age (Fig. 4b). No explanatory variables were significantly associated with spring passage rates. The best model contained only date, which was not significant (LR test $\left.\chi_{1}^{2}=2.691, P=0.101\right)$.

\section{Factors associated with movements over the ridge-top area}

Of the 474 Golden Eagles observed in the fall migration seasons, $21 \%$ ( $n=101)$ flew into the delineated buffer zone on the ridge-top area $(22 \%[n=20]$ in $2008 ; 21 \%$ [ $n=81]$ in 2009). When we included hourly passage rates in the global model, we found that the number of birds that moved over the ridge top in the fall was only correlated with hourly passage through the site; hourly movements over the ridge-top area increased by $16 \%$ with every unit increase in hourly passage through the site (LR test $\chi^{2}{ }_{1}=78.13, P \leq 0.001$ ). When we omitted overall passage rates from the model, our most parsimonious model of ridge-top movements followed a bellshaped, second-order pattern in relation to date, increased by $5 \%$ with every kilometer per hour increase in average hourly wind speed, and increased by $20 \%$ with every degree Celsius increase in average hourly temperature (LR test $\chi^{2}{ }_{1}=35.67$, $P \leq 0.001$; Table 2).

Table 2. Summary of multivariate negative binomial regression examining the association of temporal and environmental variables on Golden Eagle (Aquila chrysaetos) hourly movements over the ridge-top area in the fall at the Dokie 1 Wind Energy Project between 2 - 9 October 2008, and 13 September - 24 October 2009.

\begin{tabular}{lcccc}
\hline \hline Term & Estimate & SE & $z$ & $p$ \\
\hline Intercept $^{\dagger}$ & -5.744 & 0.974 & -5.899 & $\leq 0.001$ \\
Date $^{\ddagger}$ & 0.338 & 0.080 & 4.216 & $\leq 0.001$ \\
Date-squared $^{\S}$ & -0.007 & 0.002 & -3.801 & $\leq 0.001$ \\
Wind speed $^{\S}$ & 0.053 & 0.024 & 2.236 & 0.0253 \\
Temperature $^{\mid}$ & 0.181 & 0.041 & 4.415 & $\leq 0.001$ \\
\hline
\end{tabular}

${ }^{\dagger}$ Response is number of Golden Eagle entries per hour. For example, to estimate the number of eagles that entered the risk zone on October 1 (day 20) at a wind speed of $15 \mathrm{~km} /$ $\mathrm{hr}$, and at a temperature of $5^{\circ} \mathrm{C}, \log (\mathrm{y})=-5.744+0.338 \times$ $20-0.007^{2} \times 20+0.053 \times 15+0.181 \times 5 ; \log (\mathrm{y})=2.717$. Therefore, $\mathrm{y}=\exp ^{(2.717)}=15.13$ eagle entries $/ \mathrm{hr}$.

${ }^{\ddagger}$ Day 1 is 13 September

$\S \mathrm{km} / \mathrm{hr}$

' Degree Celsius

We found that juvenile Golden Eagles were almost twice as likely to fly over the ridge-top area in the fall compared with more experienced birds, i.e., adults and subadults (Table 3, Fig. 6). Furthermore, even though a greater overall number of fall-migrating Golden Eagles moved over the ridge-top area when they started from the western route (Fig. 7), they were almost 2.5 times more likely to move over the ridge when they started on the eastern route compared with the western, with the odds decreasing by $0.02 \%$ for every percent increase in cloud cover (LR test $\chi^{2}{ }_{1}=97.22, P \leq 0.001$; cross-validation estimate of predictable accuracy $=82.5 \%$; Table 3 ).

Table 3. Summary of logistic regression examining the association between spatial, temporal, and environmental variables on Golden Eagle (Aquila chrysaetos) flights that resulted in ridge-top movements at the Dokie 1 Wind Energy Project, British Columbia, Canada, between 2 - 9 October 2008, and 13 September - 24 October 2009.

\begin{tabular}{|c|c|c|c|c|}
\hline Term & Estimate & SE & $z$ & $p$ \\
\hline$\overline{\text { Intercept }^{\dagger}}$ & -0.197 & 0.345 & -0.571 & $\leq 0.568$ \\
\hline Route - West & -0.893 & 0.285 & -3.128 & 0.002 \\
\hline $\begin{array}{l}\text { Age - } \\
\text { Inexperienced }\end{array}$ & 0.676 & 0.277 & 2.441 & 0.015 \\
\hline Cloud cover ${ }^{\ddagger}$ & -0.012 & 0.004 & -2.638 & 0.008 \\
\hline
\end{tabular}

${ }^{\dagger}$ Response is did not fly over ridge-top area (0), or did fly over ridge-top area (1). To estimate the probability of a juvenile bird moved over the ridge-top area (as opposed to not) while using the western route under a cloud cover of $20 \%, \log (y)=-0.197+0.676-0.893-0.012 \times 20 ; \log (y)=$ -0.654 ; Therefore, $P(y)=\exp ^{(0.654)} / 1+\exp ^{(0.654)} ; P(y)=$ 0.342 .

${ }^{\ddagger}$ Percent

Fig. 6. Proportion of experienced (adult and subadult) versus inexperienced (juvenile) Golden Eagles (Aquila chrysaetos) observed entering the ridge-top area..

Individuals of unknown age not included (did not enter ridge-top area, $n=125$; entered ridge-top area, $n=18$ ). Values over bars represent sample size.

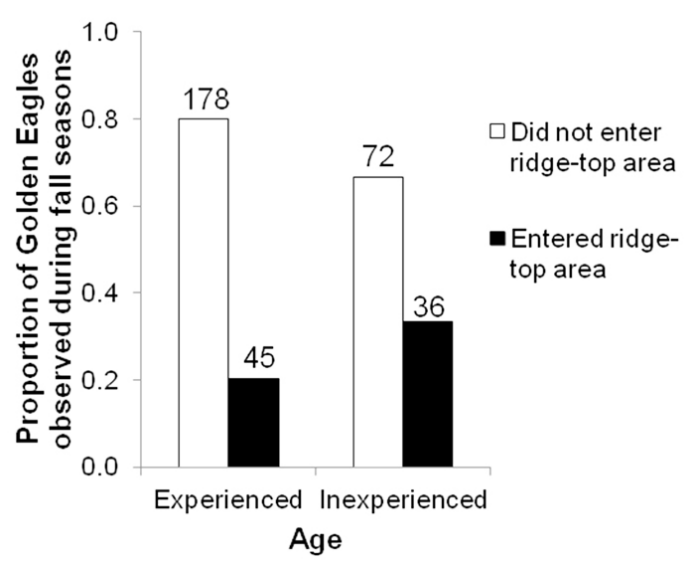


Of the 104 Golden Eagles observed in spring 2010, 26\% ( $n=$ 27 ) flew over the ridge-top area. Similar to the fall, we found that the hourly number of Golden Eagles that moved over the ridge-top area in the spring increased by $27 \%$ with every unit increase in hourly passage (LR test $\chi^{2}{ }_{1}=8.424, P=0.014$ ). For example, for every 5 eagles that passed through the site in an hour, approximately 1 eagle flew over the ridge top $(0.83$ eagles per hour). At an hourly passage of 10 eagles per hour, flights over the ridge top increased to approximately 3 eagles (2.75 eagles per hour). Like spring hourly passage, however, no weather variables were associated with flights over the ridge-top area.

Spring ridge-top movements decreased by $0.22 \%$ with every kilometer per hour increase in wind speed, and eagles were over 8 times more likely to fly over the ridge under eastern crosswinds compared with tailwinds (LR test $\chi^{2}{ }_{1}=41.58, P \leq$ 0.001 ; cross-validation estimate of predictable accuracy $=$ 78.2\%; Table 4, Fig. 7).

Table 4. Summary of logistic regression examining the association between spatial, temporal, and environmental variables on Golden Eagle (Aquila chrysaetos) flights that resulted in movements over the ridge-top area at the Dokie 1 Wind Energy Project, British Columbia, Canada, between 17 28 March 2010.

\begin{tabular}{lcccc}
\hline \hline Term & Estimate & SE & $z$ & $p$ \\
\hline Intercept $^{\dagger}$ & 1.242 & 0.518 & 2.398 & 0.017 \\
Wind speed $^{\ddagger}$ & -0.235 & 0.079 & -2.940 & 0.003 \\
Wind direction - & 2.367 & 1.995 & 1.186 & 0.235 \\
west cross wind & & & & \\
Wind direction - & -2.106 & 0.817 & -2.577 & 0.010 \\
Tail wind & & & & \\
\hline
\end{tabular}

\footnotetext{
${ }^{\dagger}$ Response is did not fly over ridge-top area (0), or did fly over ridge-top area (1). To estimate the probability of movements over the ridge-top area (as opposed to not) under a tail wind (versus an eastern cross wind) at a wind speed of $15 \mathrm{~km} / \mathrm{hr}, \log (y)=1.242-2.106-0.235 \times 15 ; \log$ $(y)=-4.389$; Therefore, $P(y)=\exp ^{(-4.389)} / 1+\exp ^{(-4.389)} ; P(y)$ $=0.012$.

${ }^{\ddagger} \mathrm{km} / \mathrm{hr}$
}

\section{Factors associated with entering the risk zone}

Of the 81 birds that flew over the ridge-top area in fall 2009 , $27 \%(n=22)$ flew within the risk zone, i.e., within the buffer zone at or below RSH ( $\leq 150 \mathrm{~m}$ agl). Sixteen of the 22 birds that entered the risk zone did so under wind speeds that would have been above turbine cut-in speed $(\geq 8.5 \mathrm{~km} / \mathrm{h}$ at ground level, or $\geq 14 \mathrm{~km} / \mathrm{h}$ at nacelle level; Fig. 8). These 16 birds that entered the risk zone during periods when turbines would have been spinning account for $20 \%$ of the eagles that flew into the buffer zone $(n=81)$ and $4 \%$ of all eagles observed in the fall $(n=382)$.
Fig. 7. Proportion of Golden Eagle (Aquila chrysaetos) flight tracks that moved over the ridge-top area by migratory route (east versus west) for the fall (2-9 October 2008 and 13 September - 24 October 2009) and spring (17-28 March 2010) migration seasons ( $n=92,399$, and 104 , respectively). East and west route signify the route taken in relation to the study ridge, Johnson Col. Individuals with unknown route not included (fall $2008 n=0$; fall 2009 $n=20$; spring $2010 n=0$ ). Values over bars represent sample size.

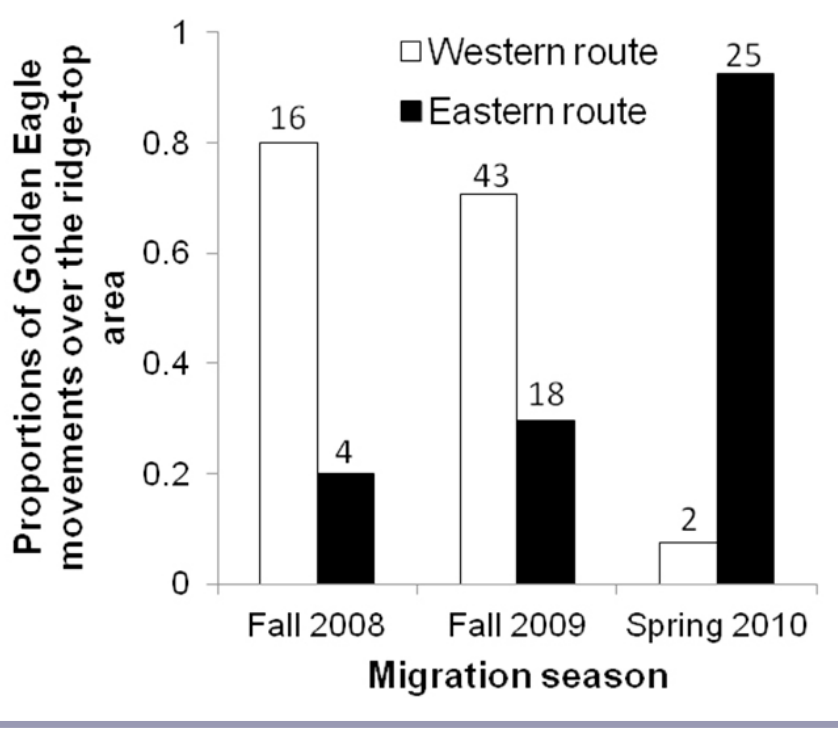

Fall entries into the risk zone were negatively associated with temperature and positively associated with wind direction. For every $1^{\circ} \mathrm{C}$ increase in temperature, the odds that a Golden Eagle entered the risk zone decreased by the ratio of 0.81 (or $0.19 \%$ ). Based on our four wind direction categories, Golden Eagles were over 7 times more likely to enter the risk zone under headwinds, and 28 times more likely under tailwinds, compared with under western crosswinds (LR test $\chi^{2}{ }_{1}=24.98$, $P \leq 0.001$; cross-validation estimate of predictable accuracy $=70.9 \%$; Table 5).

Of the 27 observed flights over the ridge-top area in the spring migration, 96\% $(n=26)$ flew into the risk zone. However, only 4 of these 26 risk-zone movements occurred during winds that were above turbine cut-in speed $(8.5 \mathrm{~km} / \mathrm{h})$. Overall, this represents $4 \%$ of all eagles observed in the spring entering the risk zone during periods when turbines would have been spinning. Too few eagles were observed for statistical evaluation of spring patterns.

\section{DISCUSSION}

Using a visual technique to translate observed movements of Golden Eagles into 3-D GIS tracks, we were able to both quantitatively assess the passage of eagles and differentiate 
Fig. 8. Number of Golden Eagles (Aquila chrysaetos) that moved over the ridge-top area by wind direction category (western cross winds [226 - 315o], head winds [136 - 225o], and tail winds [316 - 45o]) in the fall 2009. Movements over the ridge-top area include all flight altitudes $(n=81)$, whereas entries within the risk zone are within rotor-swept height (RSH) only include movements $\leq 150 \mathrm{~m}$ above ground $(n=22)$. Movements over the risk zone and at winds above turbine cut-in speed $(\geq 8.5 \mathrm{~km} / \mathrm{hr}$ ) further identifies conditions under which eagles potentially would have been at risk of being hit by a spinning turbine blade $(n=16)$. Values over bars represent sample size.

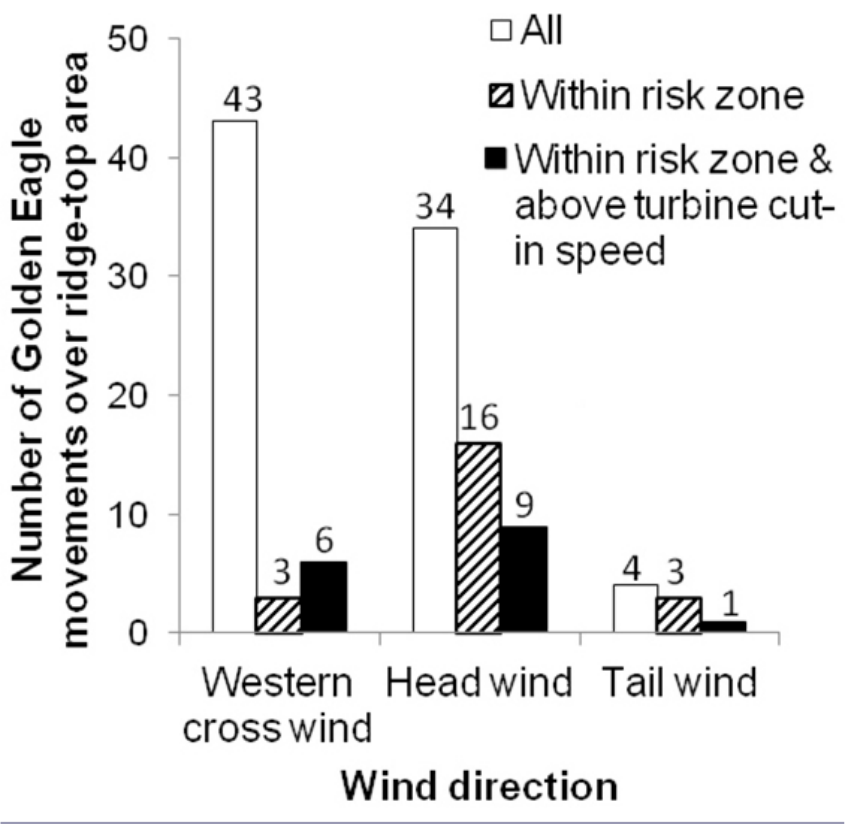

movement patterns for individuals that approached within close proximity to the proposed turbine area. We found that collision risk may be higher at this site when peak migration dates overlap with weather conditions not suitable for highaltitude lift. Poor conditions for lift occurred under weak wind conditions, which concentrated eagle passage around midday, or under strong headwinds, in which eagles were forced to travel closer to the underlying topography.

The interaction between wind speed and time of day on southbound eagle passage may be explained by the availability of good lift conditions. For example, under sufficiently strong SW winds in the fall, eagle passage commenced earlier in the day and was more consistent on an hourly basis. Such winds create strong vertically deflected air on the windward faces of ridgelines in the region, creating sequential spots of orographic lift that run parallel to the main paths of north-south migration (Ainslie et al. 2013). Under these high-wind conditions, thermals may provide less
Table 5. Summary of logistic regression examining the association between spatial, temporal, and environmental variables on Golden Eagle (Aquila chrysaetos) flights that resulted in flights into the ridge-top risk zone (100 $\mathrm{m}$ buffer area around proposed turbine string within rotor-swept height $[\mathrm{RSH} ; \leq 150 \mathrm{~m}]$ ) at the Dokie 1 Wind Energy Project between 13 September - 24 October 2009.

\begin{tabular}{lcccc}
\hline \hline Term & Estimate & SE & $z$ & $p$ \\
\hline Intercept $^{\dagger}$ & -1.228 & 0.738 & -1.665 & 0.096 \\
Temperature $^{\ddagger}$ & -0.208 & 0.109 & -1.895 & 0.058 \\
Wind & 2.111 & 0.645 & 3.271 & 0.001 \\
direction - & & & & \\
head wind & & & & \\
Wind & 3.354 & 1.389 & 2.425 & 0.016 \\
direction - tail & & & & \\
wind & & & & \\
\hline
\end{tabular}

${ }^{\dagger}$ Response is no entry (0), or entry (1) into the risk zone. To estimate the probability of an eagle entering the risk zone (as opposed to not) under head-wind conditions (versus western cross-winds) at a temperature of 5 degrees Celsius, $\log (y)=-1.228+2.111-0.208 \times 5 ; \log (y)=-$ 0.157 ; Therefore, $P(y)=\exp ^{(-0.157)} / 1+\exp ^{(-0.157)} ; P(y)$ $=0.461$.

$\doteqdot$ Degree Celsius

consistent sources of lift than vertically deflected air along the ridgelines. Duerr et al. (2012) suggested that overall migration speed would be slower, and movement trajectories more constrained to underlying topography, for birds utilizing slope soaring instead of thermals. However, the high and consistent winds during this migratory period in the eastern Rockies may benefit eagle passage because movement rates were higher and more consistent during periods in the fall when slope soaring was used, e.g., during high winds. By comparison, both early morning and late afternoon passage were low under weak winds, typically with NE winds; even though passage did increase by midday under these conditions, overall passage on these days was much lower than seen during high-wind conditions. Under such low-wind conditions, birds may not be able to initiate movement until thermal activity on the ridgelines, which is not present when strong winds dissipate warm, rising pockets of air (Shamoun-Baranes et al. 2003, Ákos et al. 2008, Chevallier et al. 2010, Duerr et al. 2012), begins to peak at midday. However, whether eagles respond to strong winds by taking flight earlier in the day or to weak winds and thermal activity by concentrating movement later in the morning, both scenarios attest to the overwhelming importance of documenting spatial and temporal patterns of movement to identify conditions of collision risk. 
It is also important to document the use of less common routes, which requires that flight path tracking be done under a range of environmental conditions. For example, despite being less frequently used, movement along the eastern route at the Dokie 1 site in the fall could pose greater proportional risk to migrating eagles if it results in greater chances of flying close to spinning turbines. We found that fall ridge-top movements at or below RSH occurred with greater frequency among eagles that both approached the site from the eastern passage route and flew under low-wind conditions. We also saw a greater proportion of ridge-top movements among eagles migrating during the spring, many of these occurring in birds approaching from the eastern route as well. This route and the associated ridge movements may also reflect prevalent lowwind conditions during the spring migration season.

Although it has been predicted that the use of orographic lift may place birds at higher collision risk because of their low relative height and reliance on the ridgelines (Duerr et al. 2012), most of this vertically rising air, and the location of eagle flight paths, occurred at the edge of the cliff lines (Ainslie et al. 2013). Turbine placement, in contrast, is set several hundred meters back where deflected air levels out as it traverses the ridgeline, the more optimal wind conditions for power generation. As a result, despite high reliance on orographic lift during the fall migration, most flights that crossed within the 100-m buffer zone around the proposed turbine string did so under weaker winds that would have generated less orographic lift. The exposed ridgelines themselves, however, may generate thermals, or rising warm air, as temperatures increase during the day, and eagles may fly at low heights along these ridgelines to take advantage of occasional thermals (Kerlinger and Moore 1989, Shannon et al. 2002, Ákos et al. 2008, Mandel et al. 2008, ShamounBaranes et al. 2010) and to maintain their overall flight altitude between ridgelines along their migration routes. The increased reliance on thermal activity under weak wind conditions could explain the higher proportion of risk-zone movements (26:1) in the spring, when average wind speeds were lower, compared with the fall $(0.4: 1)$.

The large variation in wind direction and speed between migratory seasons may also partially explain the differences in overall numbers of eagle migrants in the area. During fall migration, winds are strong and consistently from the SW; thus, they create deflected air masses that generate orographic lift but may also dissipate thermals on the ridgelines. This may cause fall-migrating eagles in the region to rely more on slope soaring than thermaling flight (Duerr et al. 2012) and thus may funnel them into regions that overlap wind developments. Spring migration was smaller, more punctuated, and less predictable with respect to weather variables because only date was significant in the models of passage rates. This might reflect higher constraints on birds to move northward to reach breeding grounds even under conditions less favorable to high- efficiency movement, but it might also be explained by differences in the spatial extent of movement in the broader region. In the spring, winds in the area are weaker and less consistent in direction, which may favor the generation of thermals inside and outside the study area; the northward migration may be more spatially diffuse as birds seek out more migration-efficient thermals rather than slope soaring (Duerr et al. 2012). Our observations in the region suggest that the northward migration may shift eastward away from the foothills into the plains, where birds may use thermals $(\mathrm{N}$. N. Johnston, J. E. Bradley, A. C. Pomeroy, and K. A. Otter, personal observations). This seasonal difference may alter the relative impacts of wind developments on eagle migration, depending on the locations of the installations.

Our finding of decreased flight altitudes associated with headwind conditions has been noted in other areas (Mueller and Berger 1967, Shamoun-Baranes et al. 2003, 2006). Under such conditions, there may be an increased likelihood of an eagle collision as the birds move closer to the underlying topography where lift is available. Postconstruction observations along with wind speed data collected at nacelle height would aid in determining the risk this represents of collision with spinning blades.

Other studies have suggested that finding a high concentration of flights into areas of proposed turbine placement during preconstruction monitoring does not necessarily correlate with the number of fatalities during postconstruction (de Lucas et al. 2007, Ferrer et al. 2012). In our preconstruction analysis, only $4 \%$ of all eagles observed migrating through the site had tracks that put them in the risk zone, i.e., turbine locations within RSH, at wind speeds that would have resulted in turbine rotation. This number is not an estimate of actual collisions, but rather an estimate of the proportion of the population that could be exposed to risk. The proportion of movements into the risk zone is anticipated to decrease significantly during postconstruction once the turbines are visible on the landscape because past research suggests that migrant eagles are able to avoid turbines (Whitfield 2009). However, support of this avoidance behavior would best be determined by postconstruction monitoring that documents flight trajectories (e.g., Desholm and Kahlert 2005), rather than estimating collision risk via carcass searches.

The technique we used of projecting visual observations into 3-D, analyzable tracks allows for such before and after study designs, and work is underway to determine whether birds are adjusting flight trajectories and routes during postconstruction. Although this technique requires a visual observer trained not only in age class and species identification, but also in distance estimation, this method has potential additive value to other employed tracking techniques. First, it has the capacity to document a large number of flight tracks, similar to radar, but has the added potential to document movement both above 
and below radar-detection elevations, as well as to provide information on species and age of targeted migrants. Although the errors in distance and height estimation are likely slightly greater than those reported with satellite tracking (e.g., Katzner et al. 2012, Lanzone et al. 2012), the potential to document a larger number of flight paths and lack of requirements to catch birds make our technique a valuable additional tool for assessing collision risk potential at proposed installations.

Our results also have implications for other wind developments in the northern Rockies region and elsewhere along this migratory corridor. Our studies were conducted near the midpoint of migration routes used by juvenile and adult eagles breeding in Alaska/Yukon and overwintering in the central United States (McIntyre et al. 2008, Bittner 2010), and wind development has begun to proliferate in the eastern foothills of the Rocky Mountains of both northeastern British Columbia, Canada, and father south in southwestern Alberta, Canada. Both the predictability of conditions that will increase passage rates, i.e., time of day, increasing wind speed, and temperature, as well as conditions that alter routes within installation sites that increase ridge-top crossings, i.e., seasonality and low wind speed, could allow for mitigation strategies to reduce eagle collisions in postconstruction. For example, de Lucas et al. (2012) report on programs in Spain where visual observers monitor risk-sensitive flight patterns of migrating Griffon Vultures (Gyps fulvus) and use this information to temporarily idle individual turbines where high movement patterns are being observed. Such techniques have led to a $50 \%$ reduction in the detected rate of vulture collisions at an estimated loss of less than $0.1 \%$ in power generation per year. Observers working at this and other installations could use predictability in movement patterns under various conditions to plan similar active mitigation programs, especially at installations, around specific turbines, or under specific conditions for which collision risk is perceived to be elevated. For example, observers tracking routes through the current installation under headwind conditions may be able to recommend idling specific high-risk turbines without large impacts on energy generation; under such conditions, the wind direction runs parallel to the orientation of the turbines, and idling of one turbine in the string is likely to be compensated by increased efficiency of the turbines that had been in its wake.

Responses to this article can be read online at: http://www.ace-eco.org/issues/responses.php/608

\section{Acknowledgments:}

We would like to thank B. H. Aukema, P. L. Jackson, C. C. St. Clair, N. Alexander, J. P. Smith, and T. Katzner and two anonymous referees for comments and contributions that greatly improved this manuscript. We would like to acknowledge and thank the West Moberly First Nations, Halfway River First Nation, Saulteau First Nations, and McLeod Lake Indian Bandfor supporting our activities in their territory. The work was funded by Environment Canada; an NSERC Strategic Projects Grant and partnership with Stantec Consulting Ltd., formerly Jacques-Whitford AXYS; EarthFirst Canada; and the Dokie General Partnership. In addition to financial support, we would like to thank and acknowledge the Dokie General Partnership for their logistic support.

\section{LITERATURE CITED}

Ainslie, B., N. Alexander, N. Johnston, J. Bradley, A. C. Pomeroy, P. L. Jackson, and K. A. Otter. 2013. Predicting spatial patterns of eagle migration using a mesoscale atmospheric model: a case study associated with a mountainridge wind development. International Journal of Biometeorology, in press. http://dx.doi.org/10.1007/ s00484-012-0620-0

Ákos, Z., M. T. Nagy , and T. S. Vicsek. 2008. Comparing bird and human soaring strategies. Proceedings of the National Academy of Sciences of the United States of America 105:4139-4143. http://dx.doi.org/10.1073/pnas.0707711105

Alerstam, T. 2001. Detours in bird migration. Journal of Theoretical Biology 209:319-331. http://dx.doi.org/10.1006/ jtbi.2001.2266

Band, W., M. Madders, and D. P. Whitfield. 2007. Developing field and analytical methods to assess avian collision risk at wind farms. Pages 259-275 in M. de Lucas, G. F. E. Janss, and M. Ferrer, editors. Birds and wind farms: risk assessment and mitigation. Quercus, Madrid, Spain.

Barrios, L., and A. Rodríguez. 2004. Behavioural and environmental correlates of soaring-bird mortality at on-shore wind turbines. Journal of Applied Ecology 41:72-81. http:// dx.doi.org/10.1111/j.1365-2664.2004.00876.x

Barrios, L., and A. Rodríguez. 2007. Spatiotemporal patterns of bird mortality at two wind farms of southern Spain. Pages 229-239 in M. de Lucas, G. F. E. Janss, and M. Ferrer, editors. Birds and wind farms: risk assessment and mitigation. Quercus, Madrid, Spain.

Batschelet, E. 1981. Circular statistics in biology. Academic Press, London, UK.

Bildstein, K. L. 2006. Migrating raptors of the world: their ecology and conservation. Cornell University Press, Ithaca, New York, USA.

Bittner, L. 2010. Satellite telemetry takes bird banding to new heights. Wild News 8:1-5.

Brodeur, S., R. Décarie, D. M. Bird, and M. Fuller. 1996. Complete migration cycle of Golden Eagles breeding in 
northern Quebec. Condor 98:293-299. http://dx.doi. org $/ 10.2307 / 1369147$

Carrete, M., J. A. Sánchez-Zapata, J. R. Benítez, M. Lobón, and J. A. Donázar. 2009. Large scale risk-assessment of windfarms on population viability of a globally endangered longlived raptor. Biological Conservation 142:2954-2961. http:// dx.doi.org/10.1016/j.biocon.2009.07.027

Chevallier, D., Y. Handrich, J.-Y. Georges, F. Baillon, P. Brossault, A. Aurouet, Y. Le Maho, and S. Massemin. 2010. Influence of weather conditions on the flight of migrating Black Storks. Proceedings of the Royal Society B: Biological Sciences 277:2755-2764. http://dx.doi.org/10.1098/rspb.2010.0422

Counihan, J. 1975. Adiabatic atmospheric boundary layers: a review and analysis of data from the period 1880-1972. Atmospheric Environment 9:871-905. http://dx.doi. org/10.1016/0004-6981(75)90088-8

Crawley, M. J. 2007. The R book. John Wiley and Sons, London, UK.

de Lucas, M., M. Ferrer, M. J. Bechard, and A. R. Muñoz. 2012. Griffon Vulture mortality at wind farms in southern Spain: distribution of fatalities and active mitigation measures. Biological Conservation 147:184-189. http://dx.doi.org/10.1016/ j.biocon.2011.12.029

de Lucas, M., G. F. E. Janss, and M. Ferrer. 2004. The effects of a wind farm on birds in a migration point: the Strait of Gibraltar. Biodiversity and Conservation 13:395-407. http:// dx.doi.org/10.1023/B:BIOC.0000006507.22024.93

de Lucas, M., G. F. E. Janss, and M. Ferrer. 2007. Wind farm effects on birds in the Strait of Gibraltar. Pages 219-228 in M. de Lucas, G. F. E. Janss, and M. Ferrer, editors. Birds and wind farms: risk assessment and mitigation. Quercus, Madrid, Spain.

de Lucas, M., G. F. E. Janss, D. P. Whitfield, and M. Ferrer. 2008. Collision fatality of raptors in wind farms does not depend on raptor abundance. Journal of Applied Ecology 45:1695-1703. http://dx.doi.org/10.1111/j.1365-2664.2008.01549. $\underline{\mathrm{X}}$

Desholm, M., and J. Kahlert. 2005. Avian collision risk at an offshore wind farm. Biology Letters 1:296-298. http://dx.doi. org/10.1098/rsbl.2005.0336

Drewitt, A. L., and R. H. W Langston. 2008. Collision effects of wind-power generators and other obstacles on birds. Annals of the New York Academy of Sciences 1134:233-266. http:// dx.doi.org/10.1196/annals.1439.015

Duerr, A. E., T. A. Miller, M. Lanzone, D. Brandes, J. Cooper, K. O'Malley, C. Maisonneuve, J. Tremblay, and T. Katzner. 2012. Testing an emerging paradigm in migration ecology shows surprising differences in efficiency between flight modes. PLoS ONE 7:e35548. http://dx.doi.org/10.1371/ journal.pone.0035548

Duinker, P., and L. Greig. 2006. The impotence of cumulative effects assessment in Canada: ailments and ideas for redeployment. Environmental Management 37:153-161. http://dx.doi.org/10.1007/s00267-004-0240-5

Ferrer, M., M. de Lucas, G. F. E. Janss, E. Casado, A. R. Muñoz, M. J. Bechard, and C. P. Calabuig. 2012. Weak relationship between risk assessment studies and recorded mortality in wind farms. Journal of Applied Ecology 49:38-46. http://dx.doi.org/10.1111/j.1365-2664.2011.02054.x

Hanafusa, T., C. B. Lee, and A. K. Lo. 1986. Dependence of the exponent in power law wind profiles on stability and height interval. Atmospheric Environment 20:2059-2066. http://dx. doi.org/10.1016/0004-6981(86)90348-3

Hedenstrom, A. 1993. Migration by soaring or flapping flight in birds: the relative importance of energy cost and speed. Philosophical Transactions of the Royal Society B: Biological Sciences 342:353-361. http://dx.doi.org/10.1098/rstb.1993.0164

Hoover, S. L., and M. L. Morrison. 2005. Behavior of redtailed hawks in a wind turbine development. Journal of Wildlife Management 69:150-159. http://dx.doi. org/10.2193/0022-541X(2005)069<0150:BORHIA>2.0.CO;2

Hunt, G. 1995. A pilot Golden Eagle population study in the Altamont Pass Wind Resource Area: population trend analysis 1994-1997. Prepared by Predatory Bird Research Group, University of California, Santa Cruz. National Renewable Energy Laboratory, Golden, Colorado, USA. http://dx.doi. org $/ 10.2172 / 86813$

Katzner, T., D. Brandes, M. Lanzone, T. Miller, and D. Ombalski. 2008. Raptors and wind energy development in the Central Appalachians: where we stand on the issue. National Aviary, Pittsburgh, Pennsylvania, USA. [online] URL: http:// docs.wind-watch.org/windenergyraptorswhitepaper.pdf

Katzner, T. E., D. Brandes, T. Miller, M. Lanzone, C. Maisonneuve, J. A. Tremblay, R. Mulvihill, and G. T. Merovich Jr. 2012. Topography drives migratory flight altitude of golden eagles: implications for on-shore wind energy development. Journal of Applied Ecology 49:1178-1186. http://dx.doi.org/10.1111/j.1365-2664.2012.02185. $\underline{\mathrm{X}}$

Kerlinger, P., and F. R. Moore. 1989. Atmospheric structure and avian migration. Pages 109-142 in D. M. Plower, editor. Current ornithology. Volume 6. Plenum Press, New York, New York, USA. http://dx.doi.org/10.1007/978-1-4757-9918-7_3

Lanzone, M. J., T. A. Miller, P. Turk, D. Brandes, C. Halverson, C. Maisonneuve, J. Tremblay, J. Cooper, K. O'Malley, R. P. Brooks, and T. Katzner. 2012. Flight responses by a migratory soaring raptor to changing 
meteorological conditions. Biology Letters 8:710-713. http:// dx.doi.org/10.1098/rsbl.2012.0359

Larson, J. 2010. Wind energy sector in British Columbia. Ministry of Energy, Mines and Petroleum Resources, Victoria, British Columbia, Canada. [online] URL: http://www.empr. gov.bc.ca/EAED/InvestmentInfo/Documents/Wind27May2010. pdf

Lekuona, J. M., and C. Ursua. 2007. Avian mortality in wind power plants of Navarra (Northern Spain). Page 177-192 in M. de Lucas, G. F. E. Janss, and M. Ferrer, editors. Birds and wind farms: risk assessment and mitigation. Quercus, Madrid, Spain.

Liguori, J. 2004. How to age Golden Eagles: techniques for birds observed in flight. Birding 36:278-283. [online] URL: http://www.aba.org/birding/v36n3p278.pdf

Maindonald, J., and J. W. Braun. 2010. Data analysis and graphics using R: an example-based approach. Third Edition. Cambridge University Press, Cambridge, UK. [online] URL: http://www.stats.uwo.ca/DAAG

Mandel, J. T., K. L. Bildstein, G. Bohrer, and D. W. Winkler. 2008. Movement ecology of migration in turkey vultures. Proceedings of the National Academy of Sciences of the United States of America. 105:19102-19107. http://dx.doi. org/10.1073/pnas.0801789105

McIntyre, C. L., D. C. Douglas, and M. W. Collopy. 2008. Movements of Golden Eagles (Aquila chrysaetos) from interior Alaska during their first year of independence. $A u k$ 125:214-224. http://dx.doi.org/10.1525/auk.2008.125.1.214

Mueller, H. C., and D. D. Berger. 1967. Fall migration of Sharp-shinned Hawks. Wilson Bulletin 79:397-415.

Omland, K. S., and S. W. Hoffman. 1996. Seasonal, diel, and spatial dispersion patterns of Golden Eagle autumn migration in southwestern Montana. Condor 98:633-636. http://dx.doi. org/10.2307/1369577

Orloff, S., and A. Flannery. 1992. Wind turbine effects on avian activity, habitat use, and mortality in Altamont Pass and Solano County Wind Resource Areas, 1989-1991. Final report by BioSystems Analysis to the California Energy Commission, P700-92-001. California Energy Commission, Sacramento, California, USA.

Segal, M., and R. A. Pielke. 1988. The extrapolation of vertical profiles of wind speed within the marine atmospheric surface layer using the $p$ formula. Journal of Applied Meteorology 27:174-181. http://dx.doi.org/10.1175/1520-0450(1988)027<0174: TEOVPO $>2.0 . \mathrm{CO} ; 2$

Shamoun-Baranes, J., W. Bouten, and E. E. van Loon. 2010. Integrating meteorology into research on migration. Integrative and Comparative Biology 50:280-292. http://dx. doi.org/10.1093/icb/icq011
Shamoun-Baranes, J., O. Liechti, Y. Yom-Tov, and Y. Leshem. 2003. Using a convection model to predict altitudes of White Stork migration over central Israel. Boundary-Layer Meteorology 107:673-681. http://dx.doi.org/10.1023/ A: 1022824008388

Shamoun-Baranes, J., E. van Loon, H. van Gasteren, J. van Belle, W. Bouten, and L. Buurma. 2006. A comparative analysis of the influence of weather on the flight altitudes of birds. Bulletin of the American Meteorological Society 87:47-61. http://dx.doi.org/10.1175/BAMS-87-1-47

Shannon, H. D., G. S. Young, M. A. Yates, M. R. Fuller, and W. S. Seegar. 2002. American White Pelican soaring flight times and altitudes relative to changes in thermal depth and intensity. Condor 104:679-683. http://dx.doi.org/10.1650/0010-5422 (2002)104[0679:AWPSFT]2.0.CO;2

Sherrington, P. 2003. Trends in a migratory population of Golden Eagle (Aquila chrysaetos) in the Canadian Rocky Mountains. Bird Trends Canada 9:34-39.

Smallwood, K. S. 2007. Estimating wind turbine-caused bird mortality. Journal of Wildlife Management 71:2781-2791. http://dx.doi.org/10.2193/2007-006

Smallwood, K. S., and B. Karas. 2009. Avian and bat fatality rates at old-generation and repowered wind turbines in California. Journal of Wildlife Management 73:1062-1071. http://dx.doi.org/10.2193/2008-464

Smallwood, K. S., and L. Neher. 2009. Map-based repowering of the Altamont Pass Wind Resource Area based on Burrowing Owl burrows, raptor flights, and collisions with wind turbines. Final Report, CEC-500-2009-065. California Energy Commission, PIER Energy-Related Environmental Research Program, Sacramento, California, USA.

Smallwood, K. S., L. Rugge, and M. L. Morrison. 2009. Influence of behavior on bird mortality in wind energy developments. Journal of Wildlife Management 73:1082-1098. http://dx.doi.org/10.2193/2008-555

Smallwood, K. S., and C. Thelander. 2004. Developing methods to reduce bird mortality in the Altamont Pass Wind Resource Area. Final report by BioResource Consultants to the California Energy Commission, Public Interest Energy Research-Environmental Area, Contract No. 500-01-019. California Energy Commission, Sacramento, California, USA.

Smallwood, K. S., and C. Thelander. 2008. Bird mortality in the Altamont Pass Wind Resource Area, California. Journal of Wildlife Management 72:215-223. http://dx.doi. org/10.2193/2007-032 
Spaar, R., and B. Bruderer. 1996. Soaring migration of Steppe Eagles (Aquila nipalensis) in southern Israel: flight behaviour under various wind and thermal conditions. Journal of Avian Biology 27:289-301. http://dx.doi.org/10.2307/3677260

Thelander, C., and L. Rugge. 2001. Examining relationships between bird risk behaviors and fatalities at the Altamont Pass Wind Resource Area: a second year's progress report. Pages 5-14 in Proceedings of the National Avian-Wind Planning Meeting IV. The Avian Subcomittee of the National Wind Coordinating Committee, Carmel, California, USA.

Venables, W. N., and B. D. Ripley. 2002. Modern applied statistics with $S$. Fourth edition. Springer, New York, New York, USA. http://dx.doi.org/10.1007/978-0-387-21706-2

Vuong, Q. H. 1989. Likelihood ratio tests for model selection of non-nested hypotheses. Econometrica 57:307-333. http:// dx.doi.org/10.2307/1912557

Weimerskirch, H., T. Guionnet, J. Martin, S. A. Shaffer, and D. P. Costa. 2000. Fast and fuel efficient? Optimal use of wind by flying albatrosses. Proceedings of the Royal Society of London B: Biological Sciences 267:1869-1874. http://dx.doi. org/10.1098/rspb.2000.1223

Whitfield, D. P. 2009. Collision avoidance of Golden Eagles at wind farms under the 'Band' collision risk model. Natural Research, Banchury, UK. [online] URL: http://www.snh.org. uk/pdfs/strategy/renewables/B362718.pdf

Yates, R. E., B. R. McClelland, P. T. McClelland, C. H. Key, and R. E. Bennetts. 2001. The influence of weather on Golden Eagle migration in northwestern Montana. Journal of Raptor Research 35:81-90.

Zoumakis, N. M. 1993. The dependence of the power-law exponent on surface roughness and stability in a neutrally and stably stratified surface boundary layer. Atmosfera 6:79-83.

Zuur, A. F., E. N. Ieno, N. J. Walker, A. A. Saveliev, and G. M. Smith. 2009. Zero-truncated and zero-inflated models for count data. Pages 261-293 in Mixed effects models and extensions in ecology with R. Springer, New York, New York, USA. http://dx.doi.org/10.1007/978-0-387-87458-6 11 